\title{
Avaliação da superfície de braquetes de titânio após a aplicação de fluoreto de sódio
}

Luciane Macedo de Menezes*, Eduardo Martinelli S. de Lima*, Susana Maria Deon Rizzatto**, Guilherme

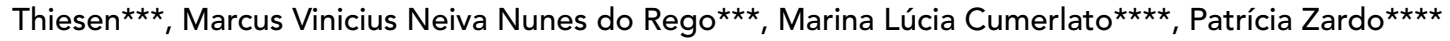

\section{Resumo}

Objetivo: avaliar o efeito da aplicação do fluoreto de sódio ( $\mathrm{NaF} 1,23 \%)$ sobre a superfície de braquetes de titânio e de aço inoxidável. Metodologia: foram utilizados 15 braquetes de titânio, divididos em três grupos: A) grupo controle, composto por braquetes não submetidos a qualquer tipo de tratamento; B) braquetes imersos por 60 segundos em fluoreto de sódio e lavados com 20ml de água destilada por trinta segundos; C) braquetes imersos por 60 segundos em fluoreto de sódio e posteriormente submetidos à escovação por 15 segundos, sendo então lavados com $20 \mathrm{ml}$ de água destilada por trinta segundos. Para efeito comparativo, foram utilizados 15 braquetes de aço inoxidável, divididos em três grupos (Grupos Al, Bl, Cl) e submetidos aos mesmos procedimentos descritos. Todos os braquetes, antes e após o experimento, foram avaliados por inspeção visual e analisados ao microscópio eletrônico de varredura (Philips, modelo XL 30). Resultados: a inspeção visual revelou uma mudança da coloração dos braquetes de titânio submetidos ao fluoreto de sódio (grupos B e C), apresentando-se escurecidos quando comparados aos acessórios do grupo A. Os braquetes de aço inoxidável não sofreram alteração cromática em nenhum dos grupos. Conclusão: através da análise por microscópio eletrônico de varredura, não foram constatadas alterações topográficas e químicas na superfície dos braquetes de titânio, assim como nos braquetes de aço inoxidável.

Palavras-chave: Braquetes de titânio. Corrosão. Fluoreto de sódio.

\section{INTRODUÇÃO E REVISÃO DE LITERATURA}

Segundo Andreasen ${ }^{1}$, houve um avanço significativo dos materiais ortodônticos nas décadas de 30 e 40, quando fios e demais acessórios de aço inoxidável se tornaram amplamente disponíveis.
Isto ocorreu principalmente após a primeira guerra mundial, com o aumento na utilização do aço inoxidável, não só na indústria como também na Odontologia, passando, assim, a substituir as ligas de ouro na confecção dos acessórios ortodônticos.

* Doutores e Mestres em Ortodontia pela UFRJ, Professores de Ortodontia da Faculdade de Odontologia da PUCRS

** Mestre em Ortodontia e Ortopedia Facial pela PUCRS. Professora de Ortodontia da Faculdade de Odontologia da PUCRS.

*** Mestres em Ortodontia e Ortopedia Facial pela PUCRS.

**** CD, Formadas no Curso de Odontologia, Faculdade de Odontologia da PUCRS. 
Os tipos mais comuns de ligas de aço austeníticos utilizadas em Ortodontia são do tipo 302 e 304, de acordo com o Instituto Americano de Ferro e Aço (American Institute of Steel and Iron, AISI), com aproximadamente $18 \%$ de cromo, $8 \%$ de níquel, o que é representado pelo grupo 18-8 de aços inoxidáveis.

No entanto, Bard ${ }^{3}$; Bass, Fine, Cisneros ${ }^{4}$; Boos e Menné ${ }^{5}$ demonstraram que têm se tornado cada vez mais freqüente a ocorrência de hipersensibilidade em alguns pacientes, causada pelo níquel presente nas ligas de aço inoxidável. Esta reação pode ser provocada pela ingestão, pelo contato direto com a mucosa e pelo contato prévio ao níquel presente em objetos metálicos como brincos e piercings ${ }^{3,6,7,19}$. Menné e Nielsen ${ }^{18}$ estimaram que $4,5 \%$ a $28,5 \%$ da população apresenta alergia ao níquel, sendo que $11,2 \%$ seriam mulheres e 2,2\% homens. Para solucionar este problema, as ligas de titânio começaram a ser utilizadas como alternativa para os pacientes que apresentam alto potencial alergênico. Além da biocompatibilidade, características como boa estabilidade dimensional, coeficientes friccionais aceitáveis, alta resistência à corrosão, rigidez e módulo de elasticidade, têm permitido o vasto uso do titânio no meio bucal 6,7,13,16. O seu uso na fabricação de fios já se encontra bastante difundido no meio ortodôntico, porém a utilização desta liga para a fabricação de braquetes é relativamente recente.

A maioria das ligas metálicas utilizadas em Odontologia, ao serem submetidas às condições da cavidade bucal, sofre um processo lento e contínuo de corrosão, sendo que a resistência a esta corrosão constitui um critério primordial para a utilização das mesmas como materiais de uso odontológico.

A superfície de todos os metais reage com o oxigênio para formar uma camada de óxidos que os proteja de uma possível corrosão, a qual, conforme observaram Janson et al. ${ }^{11,12}$, ocorre devido à ionização metálica presente quando um metal é colocado numa solução eletrolítica. Apesar da sua eletronegatividade, a resistência à degradação do titânio em soluções iônicas é superior aos demais metais devido, principalmente, à formação de uma camada protetora na superfície do titânio, conforme afirmam Deguchi et al. ${ }^{8}$ e Kapur et al. ${ }^{14}$

Esta passividade química do titânio resulta da formação, em sua superfície, de um filme de alta estabilidade, cuja espessura se encontra entre 10 e $20 \mathrm{~nm}^{3}$. Este filme protetor se desenvolve através da formação de uma camada composta por diferentes óxidos, dentre os quais o $\mathrm{TiO}_{2}$ é o mais abundante $\mathrm{e}^{9,11,13}$. Teoricamente, esta camada protetora não deveria ser danificada sob as condições encontradas no meio bucal. Entretanto, dentro da prática odontológica, a aplicação de soluções fluoretadas constituiu uma forma bastante eficaz para o controle da doença cárie, e as ligas de titânio neste meio, especificamente quando em $\mathrm{pH}$ reduzido, apresentam grande degradação. Este fenômeno é interpretado por Deguchi et al. ${ }^{8}$ e Harzer et al. ${ }^{9}$ como sendo o resultado da incorporação de íons fluoreto altamente reativos na camada de óxidos do titânio, tornando assim sua propriedade protetora consideravelmente reduzida.

Durante os últimos 50 anos, a aplicação profilática de soluções fluoretadas em intervalos regulares, realizada através do uso de géis com $\mathrm{pH}$ ácido e com alta concentração de flúor, tem-se tornado rotina na prática odontológica, alcançando notável impacto na prevenção da cárie dentária. A concentração de flúor destas soluções atinge mais de $10.000 \mathrm{ppm}$, sendo que o $\mathrm{pH}$ destas geralmente varia de 3,2 a 7,7, uma vez que, nestas condições, o efeito do gel fluoretado torna-se potencializado, com incorporação de maior quantidade de flúor na superfície dentária ${ }^{2}$. Entretanto, Bard 3 ; Bass, Fine e Cisneros ${ }^{4}$ verificaram que tais condições podem promover resultados prejudiciais às propriedades químicas e mecânicas do titânio.

Reclaru e Meyer ${ }^{22}$ sugeriram que os íons de flúor poderiam danificar a camada protetora da superfície do titânio, com aumento da rugosidade superficial e o aparecimento de falhas em sua 
superfície. Além disto, observaram aumento da corrente galvânica quando da presença de $\mathrm{pH}$ menor que 3,5 , favorecendo assim o processo de corrosão.

Ao avaliarem pastilhas de titânio imersas em soluções com diferentes concentrações de flúor e diferentes níveis de $\mathrm{pH}$, Nakagawa et al. ${ }^{20}$ relataram que o processo de corrosão ocorrido no titânio, quando da presença de íons flúor, foi dependente tanto da concentração destes íons no meio, como também do $\mathrm{pH}$ da solução. Observou-se que o titânio sofreu corrosão mesmo quando da existência de uma baixa concentração de flúor, desde que o $\mathrm{pH}$ da solução fosse baixo. Do mesmo modo, o titânio apresentou corrosão também em pH elevado, desde que a concentração de íons flúor fosse alta. Os autores concluíram que quanto maior a concentração e menor o $\mathrm{pH}$, maior a corrosão sofrida pelo titânio na superfície.

A dissolução do titânio, segundo Khan et al. ${ }^{15}$, leva à ocorrência de uma superfície totalmente rugosa no mesmo, devido à destruição da camada protetora de óxidos e à ocorrência de fendas e asperezas resultantes da degradação. Essa rugosidade pode afetar diretamente o tratamento ortodôntico, uma vez que, quanto maior a rugosidade superficial dos dispositivos utilizados, maior será a resistência friccional originada durante a mecânica de deslize, necessitando, assim, aumento na magnitude de força necessária para o deslizamento do arco pela canaleta do braquete, a fim de que ocorra a movimentação dentária ${ }^{17}$. Além disso, o aumento da rugosidade superficial do titânio, após sofrer processo corrosivo, propicia maior acúmulo de placa ${ }^{9}$.

Entretanto, quando da desestruturação ou remoção completa do filme protetor da superfície do titânio, o mesmo apresenta um potencial reparador extremamente rápido e eficaz quando as condições do meio se normalizam, ou seja, quando a concentração de flúor e o $\mathrm{pH}$ voltam aos níveis de normalidade. Assim, a camada de óxidos pode ser restituída na presença de ar ou até mesmo de pequenas quantidades de água ${ }^{20,21}$.

Ao analisarem discos de titânio puro imersos em soluções de flúor tópico, Siirilä e Könönen ${ }^{23}$ relataram que o uso controlado destas substâncias não promoveu degradação marcante na superfície deste material. Portanto, embora tenha ocorrido a corrosão do titânio quando imerso em solução com alta concentração de flúor, esta corrosão foi superficial e transitória, uma vez que a camada protetora de óxidos na superfície do titânio se recompõe rapidamente. De acordo com os autores, quando em ambiente oral, os produtos da corrosão e os íons flúor seriam rapidamente eliminados e diluídos pela saliva, bem como pela ingestão de líquidos ou outros alimentos.

Harzer et al. ${ }^{9}$ acompanharam 18 pacientes, a fim de avaliar a reação da superfície de braquetes de titânio frente às condições do ambiente bucal, com a utilização periódica de soluções contendo flúor. Nos mesmos pacientes, foram colados braquetes de titânio nos quadrantes esquerdos e braquetes de aço inoxidável nos quadrantes direitos, para fins comparativos. A avaliação macroscópica demonstrou que os braquetes de titânio apresentaram uma coloração cinza opaco, ao contrário da coloração prateada brilhante do aço inoxidável. Além disso, os braquetes de titânio apresentaram maior rugosidade superficial, proporcionando maior acúmulo de placa bacteriana. Doze meses após a colagem, os braquetes de titânio encontravam-se mais escurecidos que originalmente. $\mathrm{Na}$ avaliação microscópica, observou-se um baixo índice de fissuras ou trincas nos braquetes de titânio mesmo após exposição às soluções fluoretadas e às demais condições do meio bucal. Este fato ocorreu, provavelmente, pela ação contínua da saliva, água e alimentos, diluindo a concentração de íons flúor disponível. Deste modo, a utilização de braquetes de titânio em combinação com a aplicação de soluções fluoretadas ácidas, como por exemplo os dentifrícios, chás e géis para aplicação tópica, 
não comprometeu a longevidade dos mesmos, não sendo constatada corrosão considerável da superfície do titânio.

Ainda são bastante escassas, na literatura, informações quanto ao efeito das soluções de flúor sobre a superfície dos braquetes de titânio, bem como na desestruturação da camada protetora de dióxido de titânio. Devido a isso, o objetivo desse trabalho foi avaliar, macro e microscopicamente, o comportamento da superfície de braquetes de titânio e de aço inoxidável quando da aplicação de solução de fluoreto de sódio na forma de gel para aplicação tópica.

\section{MATERIAL E MÉTODOS}

Para análise da superfície dos braquetes após imersão em solução de fluoreto de sódio, utilizouse uma amostra constituída de 30 acessórios, sendo 15 de titânio e 15 de aço inoxidável (Fig. 1).

Os braquetes de titânio (Rematitan, marca Dentaurum) foram divididos em três grupos de 5 (A, B, C), de acordo com o tratamento de superfície a ser realizado. No grupo A não se realizou nenhum tratamento químico, sendo assim considerado como grupo controle. No grupo B os braquetes foram imersos em gel incolor de fluoreto de sódio a 1,23\% (Fluotop acidulado, marca S.S.White), por 60 segundos, e posteriormente lavados com $20 \mathrm{ml}$ de água destilada durante 20 segundos, com o auxílio de uma seringa descartável. O grupo $\mathrm{C}$ recebeu o mesmo tratamento do grupo B, acrescido de escovação por 15 segundos com uma escova elétrica (Braun Ultra Plaque Remover, marca Oral B, modelo D9511), previamente à lavagem com água destilada (Fig. 2).

Para efeito comparativo, os braquetes de aço inoxidável (Discovery, marca Dentaurum) foram divididos em três grupos (Al, Bl, Cl) e igualmente submetidos aos mesmos procedimentos dos braquetes de titânio.

A fim de comprovar o caráter acidulado do gel de fluoreto de sódio, o pH da solução foi verificado no Laboratório de Bioquímica da PUCRS, através de um pHmetro (Digimed DM-20). Após tal análise, pôde ser constatado que a solução apresentou um $\mathrm{pH}$ de 5,31. Todos os braquetes utilizados foram colocados no ultra-som (Ultra Sonic Cleaner USC 700) para limpeza da superfície dos mesmos, antes e após serem analisados ao MEV.

Os braquetes foram avaliados por inspeção visual antes e após o tratamento, relativo aos diferentes grupos.

A análise da superfície dos braquetes de titânio e de aço inoxidável foi realizada por meio de MEV (Philips modelo XL 30) na canaleta dos braquetes, com um aumento de 600X, antes e após a exposição ao fluoreto de sódio. Ainda com o auxílio do microscópio eletrônico, analisou-se a composição química dos braquetes através do programa EDS, o qual detectou os elementos presentes nesses braquetes, antes e após o experimento.

\section{RESULTADOS E DISCUSSÃO}

O titânio tem sido amplamente utilizado no meio odontológico devido às suas excelentes propriedades mecânicas, resistência à corrosão e biocompatibilidade ${ }^{22,23}$. A presença de uma camada densa e estável de óxidos de titânio em sua superfície, em especial do dióxido de titânio $\left(\mathrm{TiO}_{2}\right)$, é responsável pela sua extrema estabilidade e biocompatibilidade junto aos tecidos vivos $^{7,8}$. Entretanto, tem sido relatado que soluções com altas concentrações de fluoretos podem promover alterações deletérias na superfície deste material. Os íons de flúor presentes nas soluções odontológicas para controle da doença cárie, como dentifrícios, soluções para bochechos diários e géis para aplicação tópica podem alcançar até $1,5 \%$, ou seja, mais de $10.000 \mathrm{ppm}$. Tais concentrações são consideradas prejudiciais para a manutenção da integridade da camada protetora presente na superfície dos braquetes de titânio, comprometendo assim as suas características e favorecendo o surgimento de um processo corrosivo ${ }^{10,19}$. 


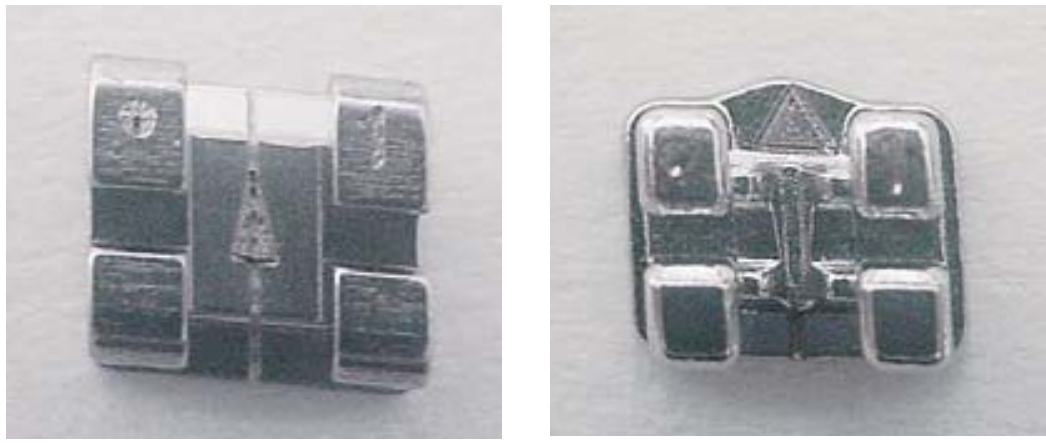

FIGURA 1 - A) Braquete de titânio (Rematitan - Dentaurum); B) Braquete de aço inoxidável (Discovery - Dentaurum).
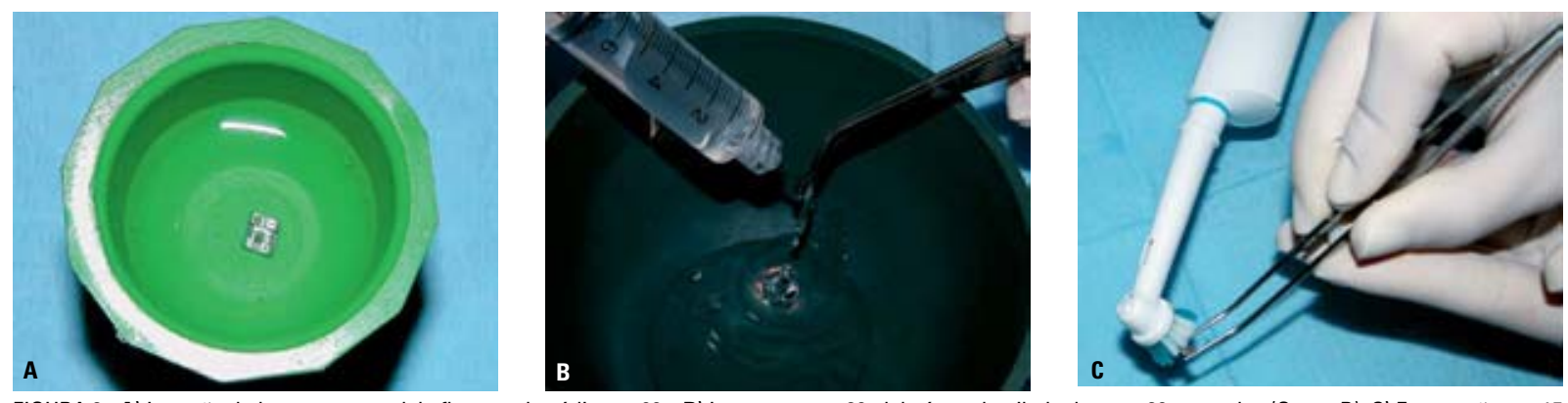

FIGURA 2 - A) Imersão do braquete no gel de fluoreto de sódio por 60s; B) Lavagem com $20 \mathrm{ml}$ de água destilada durante 20 segundos (Grupo B); C) Escovação por 15 segundos com uma escova elétrica (Braun Ultra Plaque Remover, marca Oral B, modelo D9511), previamente à lavagem com água destilada (Grupo C).

Os braquetes de titânio Rematitan (Dentaurum), utilizados neste estudo, apresentam sua composição química com menos de $0,3 \%$ de aço, $0,35 \%$ de oxigênio, $0,35 \%$ de nitrogênio, $0,05 \%$ de carbono e $0,06 \%$ de hidrogênio, sendo o restante (mais de 99\%) composto por titânio. Entretanto, a camada superficial destes braquetes apresenta de 80 a $90 \%$ de carbono e oxigênio, e apenas 10 a 15\% de titânio. O nitrogênio apresenta-se em quantidades muito menores, cerca de 1,0 a 1,5\%. Quando esta camada protetora de óxidos é danificada, ocorre o aumento da corrosão e rugosidade do titânio podendo, assim, comprometer suas características de biocompatibilidade, elevada estabilidade dimensional e baixa resistência friccional.

A análise visual prévia ao experimento revelou que os braquetes de titânio, quando comparados aos braquetes de aço inoxidável, apresentaram uma coloração mais acinzentada e opaca, conforme já relatado por Harzer et al. ${ }^{9}$, ao contrário da coloração prateada brilhante do aço inoxidável. Já a análise ao microscópio eletrônico de varredura demonstrou que os braquetes de titânio do grupo A apresentaram um aspecto mais rugoso e irregular da superfície quando comparados aos do grupo Al (Fig. 3). Harzer et al. ${ }^{9}$ também observaram esta maior rugosidade na superfície dos braquetes de titânio, fato que poderia promover um maior acúmulo de placa junto a este tipo de braquete.

Quando imersos no gel acidulado de fluoreto de sódio (grupos B e C), pôde ser observada uma reação quase imediata em sua superfície, com a formação de bolhas ao redor do braquete imerso na solução, sugerindo a ocorrência do processo corrosivo no titânio (Fig. 4). Além disso, foi possível observar uma alteração cromática significativa após 60s, com o escurecimento dos mesmos. Não foram constatadas diferenças entre os grupos B e C (com e sem escovação subseqüente) (Fig. 5). Estas alterações cromáticas não foram percebidas 

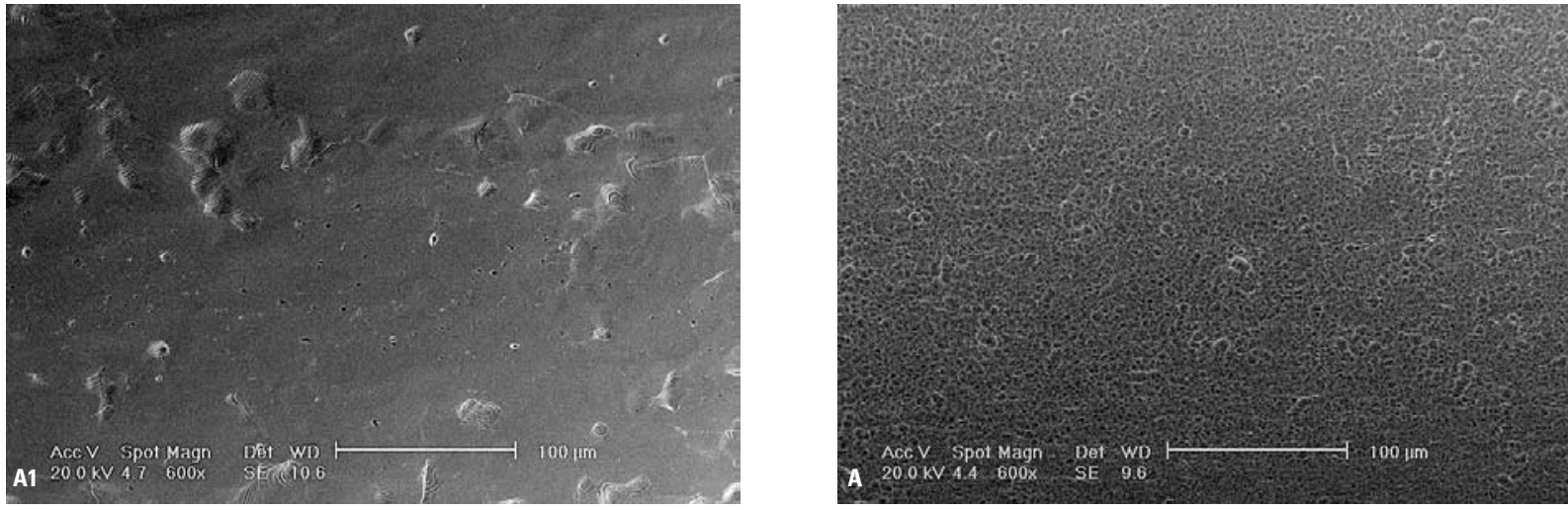

FIGURA 3 - Análise microscópica da topografia superficial dos braquetes de aço inoxidável (A1) e titânio (A), conforme recebidos do fabricante (aumento 600X).
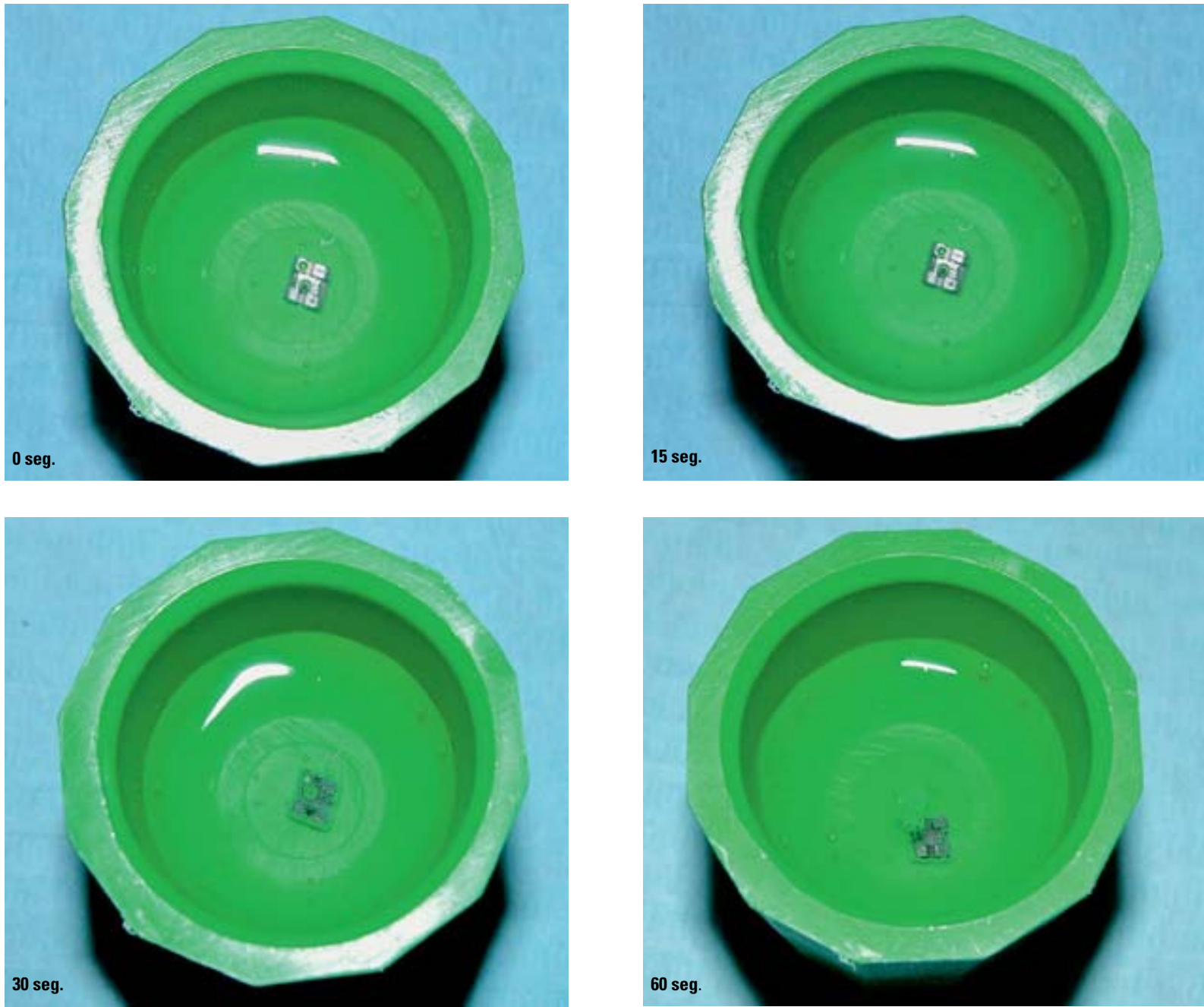

FIGURA 4 - Formação de bolhas na superfície do braquete de titânio quando imerso no gel acidulado de fluoreto de sódio a 1,23\%, sugerindo a ocorrência do processo corrosivo no titânio $(0,15,30$ e 60 segundos $)$. 


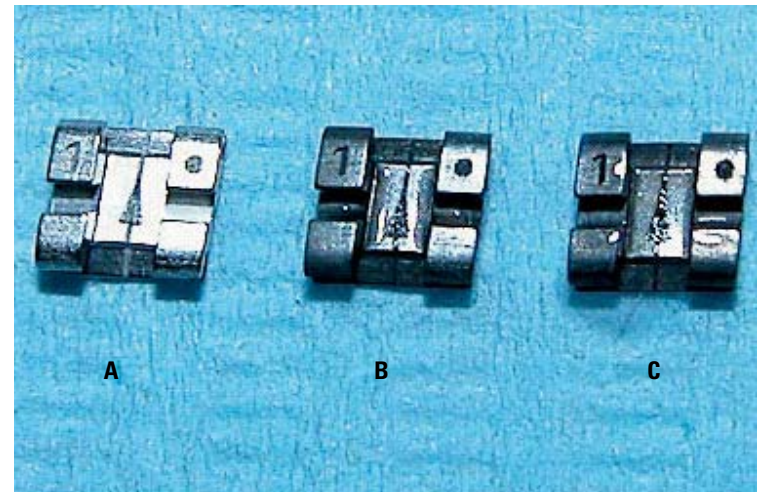

FIGURA 5 - Análise macroscópica visual dos braquetes de titânio. Alterações cromáticas ocorridas nos braquetes de titânio após a realização do experimento (grupos $\mathrm{B}$ e C).

quando da imersão dos braquetes de aço inoxidável em fluoreto de sódio (Fig. 6).

A microscopia eletrônica de varredura foi realizada para evidenciar um possível efeito corrosivo da solução de flúor na superfície dos braquetes. Nesta análise microscópica, não foram observadas alterações topográficas significativas em nenhum dos grupos de braquetes de aço inoxidável (Fig. 7) e titânio (Fig. 8) antes e após a realização do experimento. Do mesmo modo, a análise da composição química da superfície dos braquetes de titânio pelo EDS não demonstrou diferença entre os períodos pré e pós-imersão em solução fluoretada (grupos A, B e C), demonstrando que a camada protetora $\left(\mathrm{TiO}_{2}\right)$ aparentemente havia sido restabelecida (Fig. 9). Isto vai de acordo com Nakagawa et al. ${ }^{20}$, que relataram que esta película de óxidos pode rapidamente se reorganizar na presença de ar ou pequenas quantidades de água. Siirilä, Könönen ${ }^{23}$ e Canay et al. $^{7}$ também alegaram que, em caso de desestruturação mecânica desta película, ocorre uma formação bastante rápida da camada de óxidos e, assim, uma repassivação da superfície do titânio. Do mesmo modo, não foram observadas alterações químicas em todos os grupos de braquetes de aço inoxidável.

Os resultados deste estudo, apresentados no quadro 1, indicam que a aplicação por 60 segun-

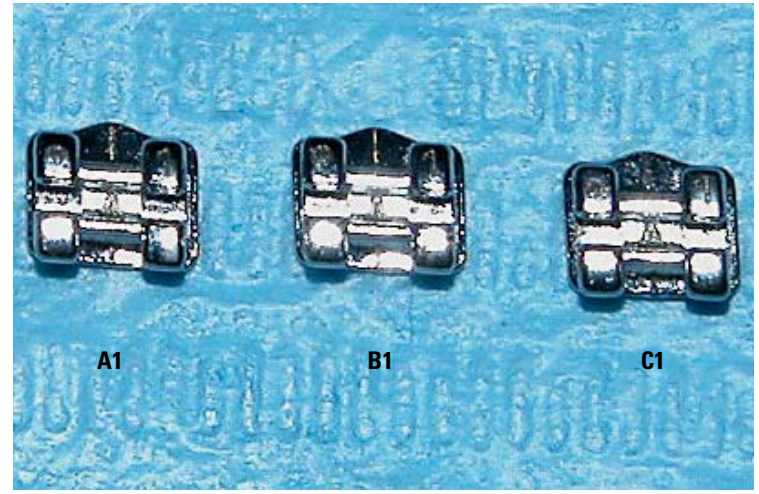

FIGURA 6 - Análise macroscópica visual dos braquetes de aço inoxidável. Não foram observadas alterações cromáticas nestes braquetes após a realização do experimento.

dos de solução tópica de flúor na forma gel, com concentração de $1,23 \%$ e pH de 5,31, apesar de provocar alteração de coloração na superfície dos braquetes de titânio, não promoveu alterações topográficas significativas nos mesmos.

No entanto, torna-se importante salientar que os pacientes que apresentam braquetes de titânio devem ser alertados quanto ao uso de agentes profiláticos à base de flúor, ressaltando que o uso indiscriminado de soluções fluoretadas provoca alterações cromáticas nos mesmos, podendo ainda vir a trazer, em longo prazo, detrimento na sua superfície. São necessários estudos adicionais que avaliem a aplicação de outras concentrações, formas e fontes de flúor sobre a superfície de braquetes de titânio, assim como a resistência friccional desses braquetes após o uso de agentes de flúor tópico.

\begin{tabular}{ccc}
\hline $\begin{array}{c}\text { Método de } \\
\text { avaliação }\end{array}$ & $\begin{array}{c}\text { Braquetes de } \\
\text { titânio }\end{array}$ & $\begin{array}{c}\text { Braquetes de aço } \\
\text { inoxidável }\end{array}$ \\
\hline Inspeção visual & $\begin{array}{c}\text { Grupos B e C } \\
\text { apresentaram-se } \\
\text { escurecidos }\end{array}$ & Sem alteração de cor \\
Análise no MEV & $\begin{array}{c}\text { Sem alteração } \\
\text { Análise EDS }\end{array}$ & Sem alteração \\
\hline
\end{tabular}

Quadro 1 - Resumo dos resultados obtidos quando avaliados os braquetes de titânio e aço inoxidável, dos grupos $A, B$ e $C$. 

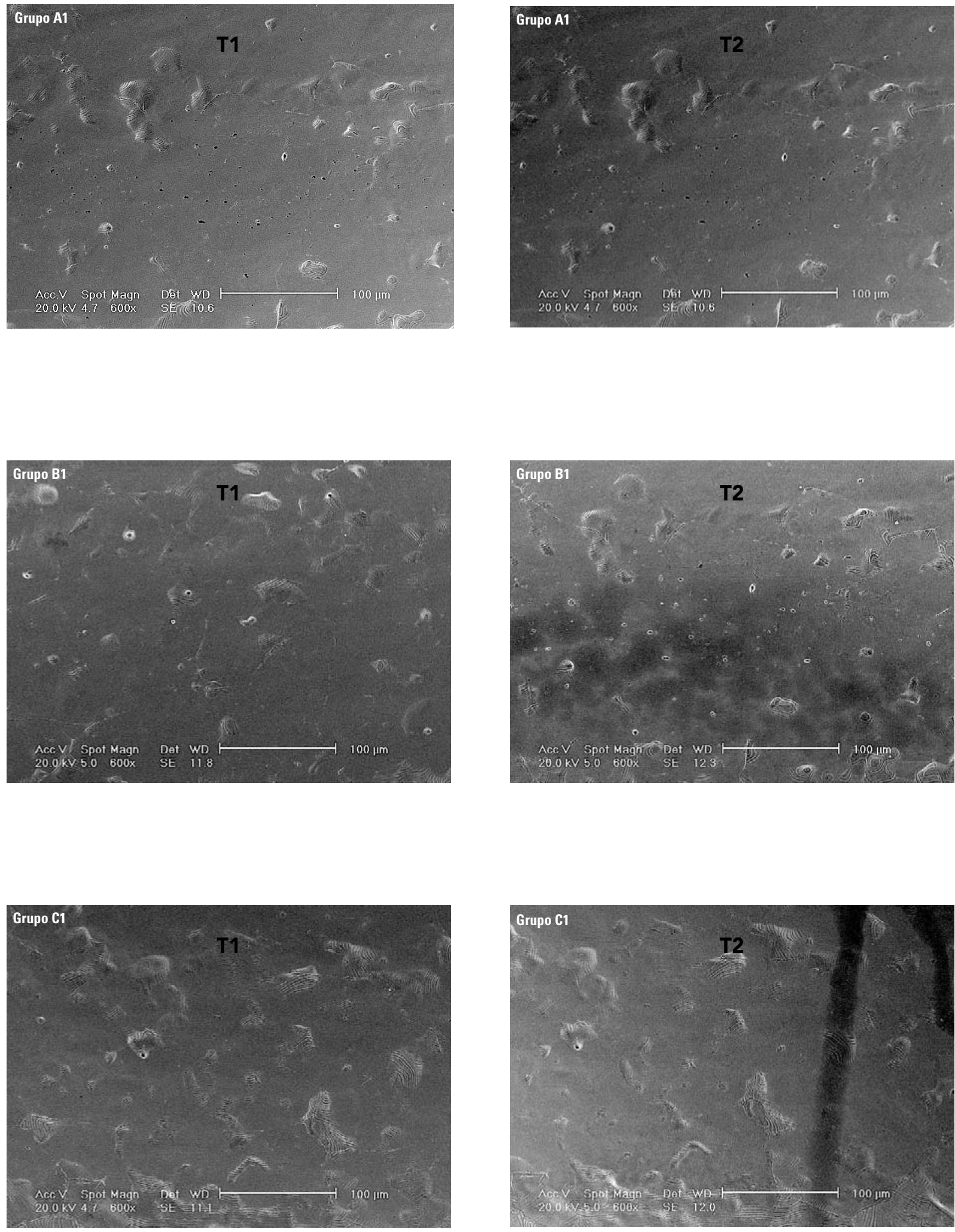

FIGURA 7 - Microscopia eletrônica de varredura avaliando a topografia superficial dos braquetes de aço inoxidável dos Grupos A1, B1 e C1 antes (T1) e após (T2) a realização do experimento (aumento 600X). 

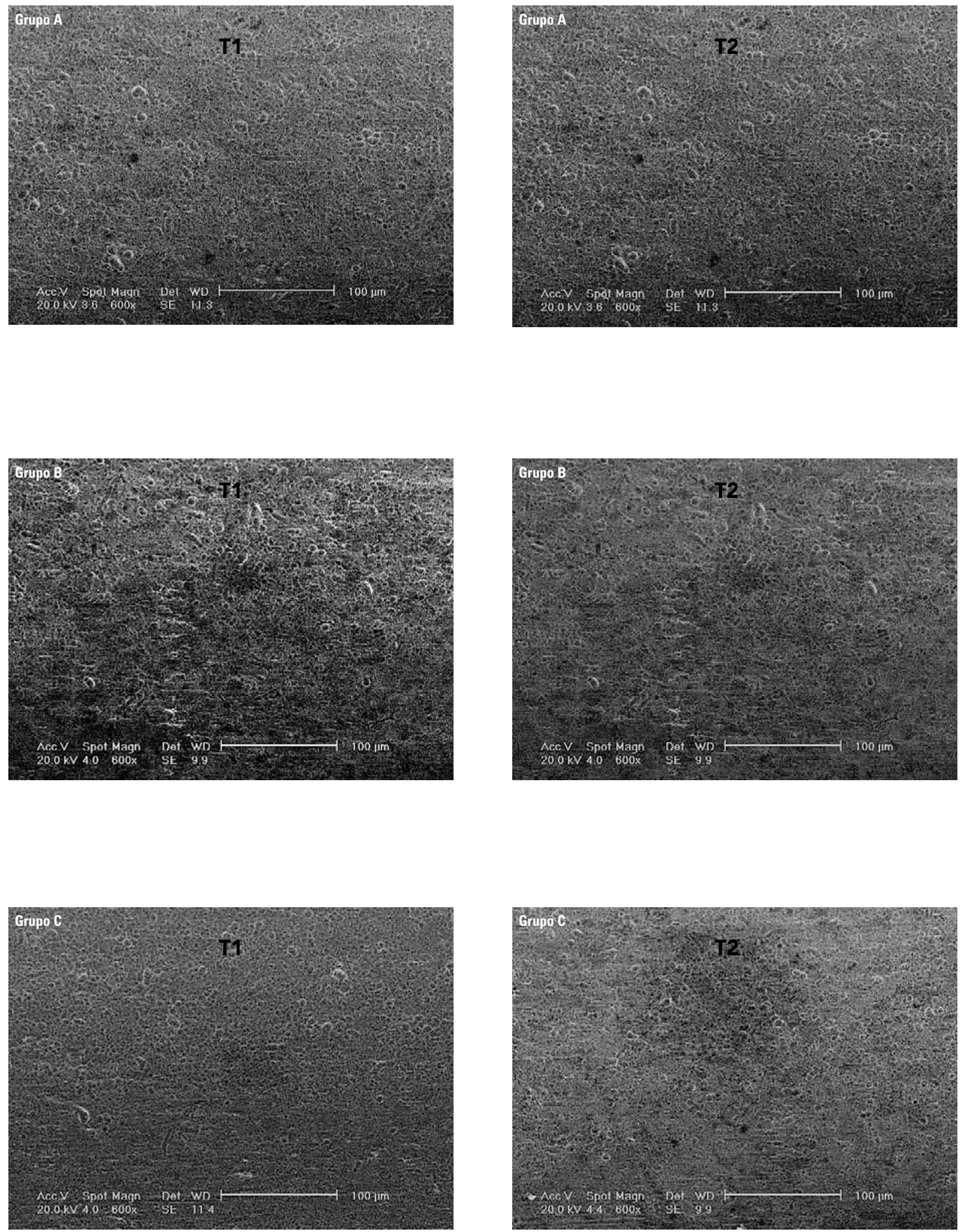

FIGURA 8 - Microscopia eletrônica de varredura avaliando a topografia superficial dos braquetes de titânio (grupos A, B e C) antes (T1) e após (T2) a realização do experimento (aumento 600X). 


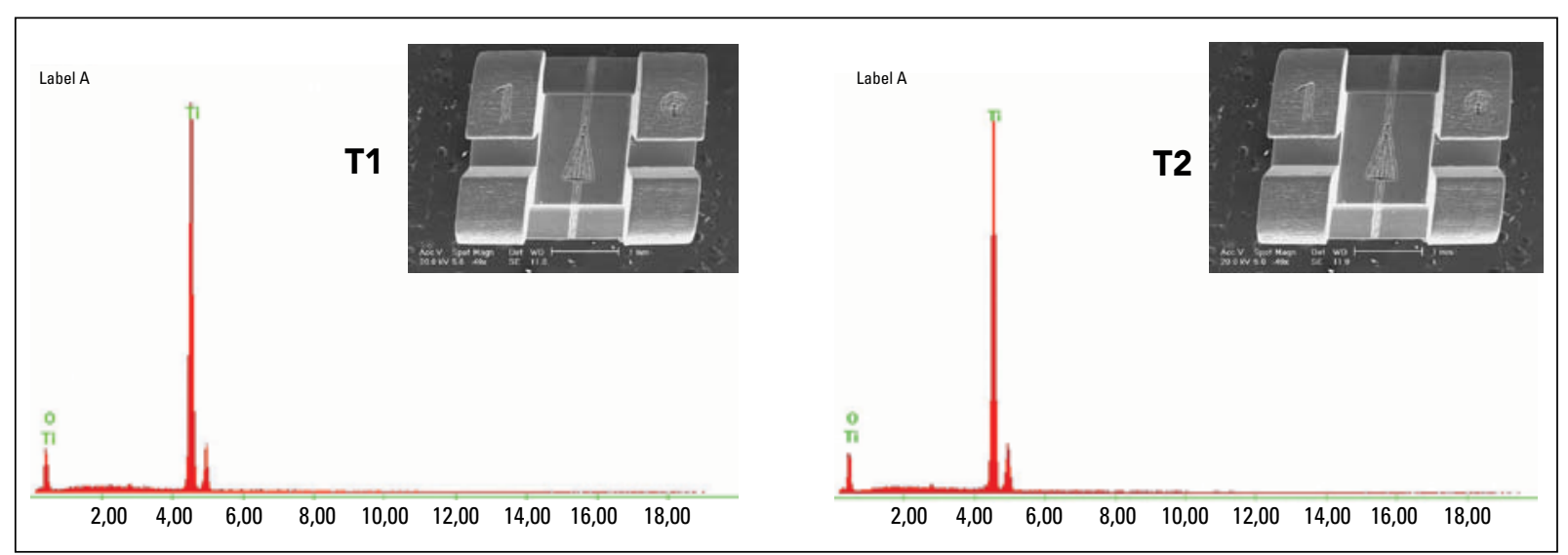

FIGURA 9 - Análise da composição química da superfície dos braquetes de titânio pelo EDS antes (T1) e após (T2) a imersão em solução fluoretada (grupo B), demonstrando a inexistência de alterações químicas em sua superfície.

\section{CONCLUSÃO}

Através da análise macro e microscópica da superfície de braquetes de titânio e de aço inoxidável, quando do emprego de géis acidulados para aplicação tópica de flúor $(1,23 \%)$, pôde-se constatar que a aplicação transitória dessa solução não promoveu alterações topográficas superficiais imediatas na superfície dos braquetes, embora a coloração dos braquetes de titânio tenha sido alterada (escureceram).

\title{
Evaluation of titanium brackets surface after immersion in sodium fluoride
}

\begin{abstract}
Aim: to assess and compare the effects of fluoride ( $\mathrm{NaF} 1.23 \%$ ) on titanium and stainless steel brackets. Methods: Fifteen titanium brackets, divided in 3 groups were used: A) control group (no treatment on its surface), B) brackets immersed in $\mathrm{NaF}$ (60 seconds) and washed with distilled water (30 seconds), C) brackets with similar treatment to group B and submitted to brushing (15 seconds). Fifteen stainless steel brackets were used for comparative effects, divided in 3 groups, and submitted to the same described procedures. All brackets were evaluated by macroscopic (visual appearence) and scanning microscopy (Philips, model XL 30), before and after the procedures. Results: titanium brackets submitted to fluoride (NaF), groups $\mathrm{B}$ and $\mathrm{C}$, presented discoloration (matte gray color) when compared to group A. Stainless steel brackets showed no color alteration. Conclusion: titanium and stainless steel brackets showed no change in surface roughness or chemical components when immersed in sodium fluoride solution.
\end{abstract}

Key words: Titanium brackets. Corrosion. Sodium fluoride.

\section{REFERÊNCIAS}

1. ANDREASEN, G. F. Selection of the square and rectagular wires in clinical practice. Angle Orthod, Appleton, v. 42, no. 1, p. 81-84, Jan. 1972.
2. BARATIERI, L. N.; ANDRADA, M. A. C.; MONTEIRO JÚNIOR, S et al. Dentística: procedimentos preventivos e restauradores. 2. ed. São Paulo: Ed. Santos, 1993.

3. BARD, J. A. Encyclopedia of electrochemistry of the elements. In: JAMES, W. J.; STRAUMANIS, M. E. (Ed.). Titanium. New York: Marcel Dekker, 1976. v. 1, p. 305-395. 
4. BASS, J. K.; FINE, H.; CISNEROS, G. J. Nickel hypersensitivity in the orthodontic patient. Am J Orthod Dentofacial Orthop, St. Louis, v. 103, no. 3, p. 280-285, mar. 1993.

5. BOOS, A.; MENNÉ, T. Nickel sensitization from ear piercing. Contac Dermat, Copenhagen, v. 8, no. 3, p. 211-213, may 1982.

6. BÜYÜKYILMAZ, T.; OGAARD, B.; DAHM, S. The effect on the tensile bond strength of orthodontic brackets of titanium tetrafluoride (TiF) application after acid etching. Am J Orthod Dentofacial Orthop, St. Louis, v. 108, no. 3, p. 256-261, sept. 1995.

7. CANAY, S.; HERSEK, N.; CULHA, A.; BILGIC, S. Evaluation of titanium in oral conditions and its electrochemical corrosion behaviour. J Oral Rehabil, Oxford, v. 23, no. 10, p. 759-764, oct. 1998.

8. DEGUCHI, T.; OBATA, A.; YAMAGISHI, T.; OSHIDA, Y. Trial production of titanium orthodontic brackets fabricated by metal injection molding (MIM) with sintering. J Dent Res, Alexandria, v. 75, no. 7, p. 1491-1496, july 1996.

9. HARZER, W.; SCHRÖTER, A.; GEDRANGE, T.; MUSCHTER, F. Sensitivity of titanium brackets to the corrosive influence of fluoride-containing toothpaste and tea. Angle Orthod, Appleton, v. 71, no. 4, p. 318-323, 2001.

10. HUANG, H. H. Effects of fluoride concentration and elastic tensile strain on the corrosion resistance of commercially pure titanium. Biomaterials, Oxford, v. 23, no. 1, p. 59-63, jan. 2002.

11. JANSON, G. R. P.; DAINESI, E. A.; CONSOLARO, A.; WOODSIDE, D. G.; FREITAS, M. R. Nickel hypersensitivity reaction before, during and after orthodontic therapy. Am J Orthod Dentofacial Orthop, St. Louis, v. 113, no. 6, p. 655-660, june 1998.

12. JANSON, G. R. P.; DAINESI, E. A.; PEREIRA, A. C. J.; PINZAN, A. Clinical evaluation of nickel hypersensitivity reaction in patients under orthodontic treatment. Ortodontia, São Paulo, v. 27, p. 31-37, 1994.

13. KAPUR, R.; SINHA, P. K.; NANDA, E. S. Comparison of load transmission and bracket deformation between titanium and stainless brackets. Am J Orthod Dentofacial Orthop, St. Louis, v. 116 , no. 3, p. 275-278, sept. 1999.

14. KAPUR, R.; SINHA, P. K.; NANDA, E. S. Comparison of frictional resistance in titanium and stainless steel brackets. Am J Orthod Dentofacial Orthop, St. Louis, v. 116, no. 3, p. 271-274, sept. 1999.

15. KHAN, M. A.; WILLIAMS, R. L.; WILLIAMS, D. F. In-vitro corrosion and wear of titanium alloys in the biological environment. Biomaterials, Oxford, v. 17, no. 22, p. 2117-26, nov. 1996.

16. KUSY, R. P.; WHITLEY, J. Q.; AMBROSE, W. W.; NEWMAN, J. G. Evaluation of titanium brackets for orthodontic treatment. Part I. The passive configuration. Am J Orthod Dentofacial Orthop, St. Louis, v.114, no. 5, p. 558-572, nov. 1998.

17. LOFTUS, B.; ARTUN, J.; NICHOLLS, J. I.; ALONZO, T.; STONER, J. A. Evaluation of friction during sliding tooth movement in various bracket-arch wire combinations. Am J Orthod Dentofacial Orthop, St. Louis, v. 116, no. 3, p. 336-345, sept. 1999.

18. MENNÉ, T.; NIELSEN, N. H. Nickel sensitization and ear piercing in an unselect danish population. Glostrup allergy study. Contact Dermatitis, Copenhagen, v. 29, no. 1, p. 16-21, july 1993.

19. MENEZES, L. M. Reações aos metais utilizados em Ortodontia. 2000. $136 \mathrm{f}$. Tese (Doutorado em Ortodontia)-Faculdade de Odontologia, Universidade Federal do Rio de Janeiro, Rio de Janeiro, 2000.

20. NAKAGAWA, M.; MATSUYA, S.; SHIRAISHI, T.; OHTA, M. Effect of fluoride concentration and $\mathrm{pH}$ on corrosion behavior of titanium for dental use. J Dent Res, Alexandria, v. 78, no. 9, p. 1568-1572, sept. 1999.

21. NAKAGAWA, M.; MATSUYA, S.; UDOH, K. Corrosion behavior of pure titanium and titanium alloys in fluoride-containing solutions. Dent Materials J, Tokyo, v. 20, no. 4, p. 305-314, dec. 2001.

22. RECLARU, L.; MEYER, J. M. Effects of fluorides on titanium and other dental alloys in dentistry. Biomaterials, Oxford, v. 19, no. 1/3, p. 85-92, jan./feb. 1998.

23. SIIRILÄ, H. S.; KÖNÖNEN, M. The effect of oral topical fluorides on the surface of commercially pure titanium. Int J Oral Maxillofac Implants, Carol Stream, v. 6, no. 1, p. 50-54, spring 1991.
Endereço de correspondência

Luciane Macedo de Menezes

PUC-RS - Faculdade de Odontologia - Departamento de

Odontologia Preventiva - Disciplina de Ortodontia

Av. Ipiranga, 6681 - prédio 06

CEP: $90.619-900$ - Porto Alegre/ RS

Caixa Postal: 1429

E-mail: luciane@portoweb.com.br 